\title{
Adult Immunization
}

\author{
Sujit K Bhattacharya* and Sabahat Azim \\ Glocal Healthcare systems Pvt Ltd, India
}

Submission: October 15, 2017; Published: October 24, 2017

*Corresponding author: Sujit K Bhattacharya, Glocal Healthcare systems Pvt. Ltd, Kolkata, India, Tel: 8697462003;

Email: sujitkbhattacharya@yahoo.com

\section{Opinion}

Immunization is an attractive disease prevention strategy. This refers to the building up of the capacity of the body to create a response to defend against the invading foreign agent (s). This building up of the process is called immunization. The first successful vaccine developed was Smallpox vaccine by Edward Jenner in 1796. He followed up his observation that milkmaids who had previously caught cowpox did not later contracted smallpox. He showed that inoculated cowpox protected against inoculated smallpox. This remarkable discovery paved the way to undertake Smallpox eradication form the globe. This was possible because there were no extra human reservoir(s) of the virus (except monkey pox). The last case of Smallpox was reported in December 1977 from Somalia. It was concluded that smallpox had been eradicated; a conclusion endorsed by the WHO General Assembly in May 1980.

Immunization results in production of antibodies against the offending agent (humoral immunity) or helps development of delayed hypersensitiy (e.g. Tuberculosis, Leprosy). This type of immunity is called active immunity. On the other hand, transfer of antibodies to confer rapid immunity is called passive immunity (e.g. transfer of immunoglobulin). However, when the immune system of the body fails to recognize its own antigens and produce antibodies and antigen-antibody reactions occur resulting in destruction and impaired functioning of the organ (s) (e.g. Hashimato's thyroiditis). This recognition of self as non self is called autoimmune reaction or disease.

Immunization was generally considered as the domain of infants and young children. This is typified by the introduction of Triple antigen, Oral Polio, Mumps and Measles vaccination (Triple antigen \& MMR) as expanded immunization programmed
(EPI) [1]. The immunization of children over many years no doubt protected them, but over the years the immunity fell down and in adulthood they became vulnerable to these diseases. Currently, diphtheria is seen in adults also [2]. A strong suspicion will be required for early diagnosis in adults. In view of this, the policy of immunization recommendation has required a relook.

A host of vaccines are now available, e.g. Polio, Chickenpox, Hepatitis, Dengue, Chickungunia, Japanese encephalitis, Pneumococcal \& Meningococcal, Oral cholera Vaccine, Influenza, Haemophilus Influenza B, Rotavirus, Rabies, Typhoid, Yellow Fever, Tuberculosis, Anthrax, HPV, Malaria and HIV. Some of them are in developmental stage, e.g. HIV, Tuberculosis. Some of these vaccines are also required for infants and children [3].

A few aspects should be addressed in such situation. Maintenance of cold chain is absolutely necessary. Not all vaccines are giving $100 \%$ protection, e.g. Dengue, Cholera, while Smallpox vaccination gives lifelong protection. Encouraged by Smallpox eradication, Polio eradication has been successfully completed. Technical assistance from WHO was available for the countries and this was crucial to the success. New and reemerging diseases warrant strict surveillance and as and when required develop vaccines to combat these new and emerging diseases. Recombinant technology has been very useful.

\section{References}

1. Advisory Committee on Immunization Practices (2000) Use off anthrax vaccine in the United States. MMWR Recomm Rep 49(RR-15): $1-20$.

2. Immunization Action Coalition (IAC) (2004) A step by step guides St Paul: Centers for disease control and prevention.

3. https://www.cdc.gov/vaccines/pubs/pinkbook/downloads/prinvac. pdf 


\section{Your next submission with Juniper Publishers will reach you the below assets}

- Quality Editorial service

- Swift Peer Review

- Reprints availability

- E-prints Service

- Manuscript Podcast for convenient understanding

- Global attainment for your research

- Manuscript accessibility in different formats

( Pdf, E-pub, Full Text, Audio)

- Unceasing customer service

Track the below URL for one-step submission https://juniperpublishers.com/online-submission.php 